\title{
Climate Change in the Theory of Finance
}

\author{
Oluseun A. Paseda ${ }^{1} \quad$ Ogochukwu Okanya $^{2 *}$ \\ 1.Department of Banking and Finance, School of Economics, University of Ibadan, Nigeria \\ 2.Department of Banking and Finance, Institute of Management and Technology, Enugu, Nigeria
}

\begin{abstract}
Finance scholars are only recently attempting to bridge the gap in climate finance. This paper is essentially a literature review of the interaction of climate change and finance through the lens of financial theory. The demand for financing climate-resilient infrastructures such as clean energy projects, energy-efficient buildings, low-carbon transportation, water, waste management systems, and the supply side of financing these infrastructures was reviewed. Financial theories and frameworks such as the Modigliani and Miller theorem, capital asset pricing model (CAPM), option pricing, efficient market hypothesis, and agency theory were also amenable to analyzing climate change and finance problems. Specifically, the factors to consider when financing and funding climateresilient infrastructure include the financing profile of the investment; potential for cost recovery from users; the extent to which quality is contractible; the level of uncertainty and complexity of the project and policy frameworks; financial market conditions; and optimal allocation of risks. As data collection improves, climate finance research can continue on a great ride with enormous benefits to the global community.
\end{abstract}

Keywords: Climate risk, Modigliani and Miller theorem, Asset pricing, Efficient capital markets, Option pricing. DOI: $10.7176 / \mathrm{JESD} / 11-18-04$

Publication date:September $30^{\text {th }} 2020$

\section{Introduction}

The earth's average temperature of about $15^{\circ} \mathrm{C}$ in May 2020 was not unusual given past fluctuations. There are natural fluctuations in climate temperature as well as changes due to human causes. Nature-induced increment in temperature is linked to the greenhouse effect, which describes how the atmosphere traps some of the Sun's energy. Solar energy radiating back to space is absorbed by greenhouse gases (GHG) and re-emitted in all directions. The solar energy heats the earth's atmosphere and the planet's surface such that in the absence of this greenhouse effect, the world would have been much colder and uninhabitable. However, scientists believe that humans add to the natural greenhouse effect through greenhouse gas emissions from industry and agriculture, trapping more energy and increasing the temperature. The real extent of the environmental- impact-induced-climate change remains uncertain though recent scientific evidence, as documented by the Intergovernmental Panel on Climate Change (IPCC, 2018), is increasingly worrisome. Many public and private institutions are attempting to take steps toward averting a catastrophe. Figure 1 below shows a 140-year trend (1880-2020) in the change in the earth's average temperature. The "human drivers only" trend-line of increase in global temperature is highly correlated with observed temperatures implying that it can be within the control of humans to address the risk of global warming. Figure 1: Climate Variability and Climate Change Over the 140 years 1880-2020

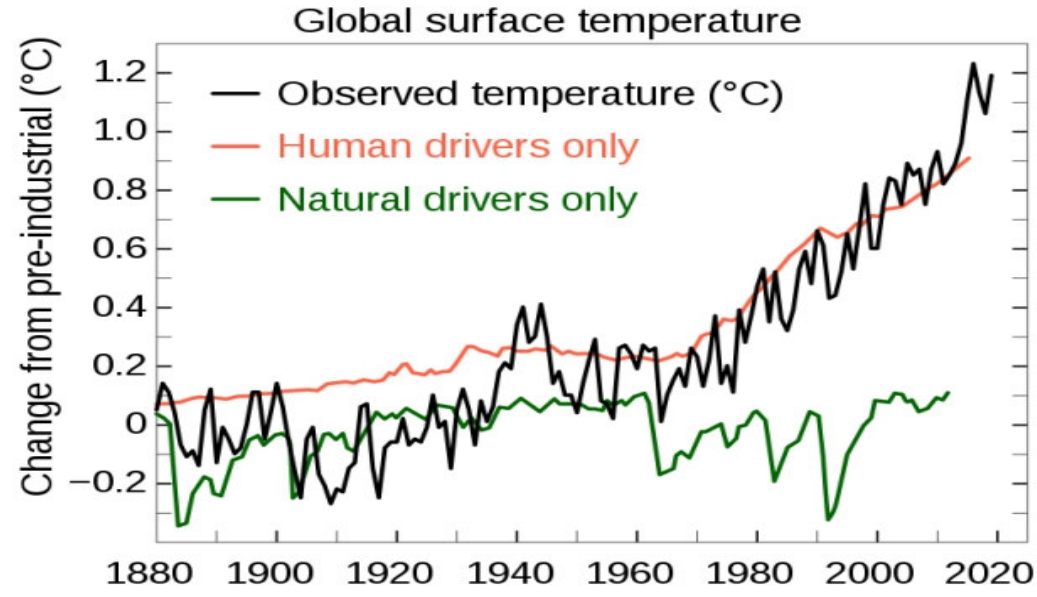

Source: Wikipedia

A few of the critical questions that have occupied climate change researchers include: Who will provide finance and at what levels? How will the international agreements on climate change encourage countries to mobilize finance domestically? How will finance for adaptation work? How will international climate agreements ensure better reporting of how finance flows? Further, many sectors within the global economy ranging from energy, buildings/real estate, transportation, food, and financial sectors are directly impacted by the risks generated 
by carbon emissions and potential carbon pricing. Underlying these concerns are challenging questions concerning the distribution of damage functions from global warming or heating (Choi, Gao \& Jiang, 2020). Practitioners and researchers have concerned themselves with tasks such as estimating the impact of climate change on properties especially real estate (Murfin \& Spiegel, 2020; Baldauf, Garlappi \& Yannelis, 2020); deriving appropriate discount rates for carbon pricing (Giglio, Maggiori, Stroebel, \&Weber, 2019); carbon $\left(\mathrm{CO}_{2}\right)$ and greenhouse gas (GHG) emissions mitigation; evaluating the ability of capital markets to impound these risks into market prices (Hong, Li \& Yu, 2019).

Additionally, the practitioners and researchers provide a platform for raising large sums that could help households, corporations, and other institutions that hedge climate change risks (Engle, Giglio, Kelly, Lee \& Stroebel, 2020). Answers to these questions depend on the expectations of economic agents. The famous Paris Climate Agreement has prompted efforts to mobilize initiatives such as the Climate Finance Leadership Initiative and many national launched principles of sustainable or responsible banking. Such sustainable investing and financing actions can potentially influence the cost of capital for large $\mathrm{CO}_{2}$ emissions companies - even in the face of carbon taxes - and by extension, corporate investment behavior. Raising the trillions necessary over the coming decades to address global warming will undoubtedly rely on financial innovations (Hong, Karolyi \& Scheinkman, 2020: 1012). William Nordhaus' 2018 Nobel Prize in Economics for work done on climate models since the 1970s reminds financial economists of missed research opportunities in the area of climate finance.

Consequently, some emerging climate finance research areas include the use of capital markets to create market-based emissions trading systems (Nordhaus (1994, 2013, 2015, 2016, 2017a, 2017b), Stern, 2013, Golosov, Hassler, Krusell, \& Tsyvinski, 2014)), the efficiency of the market pricing of climatic risks (Cohen \& Frazzini, 2008; Bansal, Ochoa, \& Kiku, 2016; Barnett, Brock \& Hansen, 2020; Alok, Kumar \& Wermers, 2020), the role of venture capital and alternative finance to develop new low-emissions technologies (Aglietta \& Espagne, 2016), the climate risks assessment and disclosure for banks and non-financial companies (Battiston, Mandel, Monasterolo, Schütze, \&Visentin, 2017), the contribution of project finance and private equity to building clean energy projects (Steffen, 2018; Colenbrander, Dodman, \& Mitlin, 2018), the financial management decisions affected by climate risks and policies, the corporate governance conflicts and incentives in addressing climate risks (Shive \& Forster, 2020), and the design of investment strategies to hedge climate risks and liabilities.

Some scholars have attempted to investigate the interaction between climate change risk and efficient market hypothesis. The efficient market hypothesis hypothesizes that market prices reflect all relevant information so that market participants cannot design trading rules based on such information to earn superior returns. Roll (1984), Campbell \& Diebold (2005), Deschenes \& Greenstone (2007), Schlenker \& Roberts (2009), and Dell, Jones \& Olken (2014) examine the impact of short-term fluctuations in weather on the pricing of weather derivatives. Hong, $\mathrm{Li} \& \mathrm{Xu}$ (2019) consider the effect of drought on the pricing of food industry stocks across 31 countries to determine if market prices efficiently discount drought risks across the selected countries. Hong, Li \& Xu (2019) develop and test their hypothesis in three steps. First, they measure time trends in droughts across countries with publicly-traded equities in the food industry and categorize countries into those with negative (or adverse trends) versus those with nonnegative (or in some instances even positive trends) by using publicly available data up to a given year $t$. Hong, Li \& Xu (2019) then document the trend rankings, measured using data only up to year $t$, and forecast the relative performance of the food industry based on cash flows (in years $t+1, t+2,$. ). Their findings affirm that food industries in countries with negative trends subsequently experienced weak profit growth relative to the food industries in countries with positive trends. Using asset pricing models such as the Sharpe (1964) CAPM, Carhart (1997) four-factor model and other multi-factor models (utilized empirically by Fama \& French (2020) and Brennan \& Zhang (2020)), or the currency factor model of Lustig, Roussanov \& Verdelhan (2011), Hong, et al. (2019) find significant under-reaction effects of climate risks on market prices. Their analysis suggests that climate risk information is incorporated into stock prices with "significant delay." This evidence is not conclusive in the empirical literature (Barro, 2015; Bernstein, Gustafson \& Lewis, 2019).

Understanding the role of financial markets in pricing climate risks is natural, though work is limited at this point, with some notable exceptions. Bansal, Ochoa, \& Kiku (2016) argue that long-run climate risks captured by temperature are priced into the market. Giglio, Maggaiori, Stroebel \& Weber (2015) and Daniel, Litterman \& Wagner (2018) show how stock and real estate market might help guide government policies assuming market efficiency incorporates such climate risks.

This paper seeks to provide a conceptual framework that links some of the emerging issues on climate change to fundamental theories in finance. Traditionally, climate change is usually considered as negative externality against which society can insulate itself via a carbon tax or an emission trading market. It is only with the efficient market hypothesis (EMH) that climate risk effects are adequately incorporated into market prices. There is little chance then that such a simple approach to climate policy succeeds in mitigating climate damage. There is a strong possibility that financial and climate fragility re-enforce each other through at least five channels, namely:

(1) Climate change destroys physical property that might have been financed by financial institutions;

(2) Climate risks may affect the credit risks of financial transactions through climatic shocks that could 
weaken the financial conditions of borrowers;

(3) Climate change could impair financial markets when climate-induced disasters adversely impact on corporate profitability and cash flows systematically;

(4) Policy pathways designed to address climate change embody financial risks because a shift from a carbonintensive economy may adversely impact the business model of fossil fuel-intensive businesses leading to "stranded assets."

(5) Systemic risk resulting from climate change is potentially damaging to the economy.

Climate change can be related to the theory of finance. Some of the seminal theories upon which modern finance is founded are utility theory, state-preference theory, mean-variance portfolio theory, capital asset pricing model (CAPM) and its various extensions (including the arbitrage pricing theory, APT), option pricing theory, agency theory, efficient market hypothesis, and the Modigliani-Miller (MM) theorems.

Their common theme revolves around how individuals and society allocate scarce resources through a price system based on the valuation of risky assets. Utility theory thus provides the basis of rational decision making in the face of risky alternatives such as a trade-off between incurring a carbon tax and reputational damage on one hand and profitability on the other hand in a firm's production and operating decisions. Another trade-off could arise between industrial activities that generate employment opportunities at the cost of a warmer more polluted environment. In mainstream finance, the objects of choice are described by state-preference theory, mean-variance portfolio theory, capital asset pricing model, and option pricing theory. When the theory of choice is combined with the objects of choice, such fusion yields the model for valuing risky alternatives. When correctly assigned, the efficient market hypothesis posits that market prices provide useful signals to the economy to guide efficient resource allocation. Finally, the Modigliani-Miller theory asks, "Does the method of financing impact the firm's value?" The answer to this question has far-reaching implications for the firm's choice of capital structure (debtto-equity mix) and dividend policy (Modigliani \& Miller, 1958; Miller \& Modigliani, 1961). Some of the analytical framework utilized at the micro-firm level has been extended to the analysis of economic aggregates of the capital structure of firms, debt policy of nations and agency theory at both firms- and economy wide-level (Modigliani \& Miller, 1958; 1963; Jensen \& Meckling, 1976; Jensen, 1986; Miller, 1977; Miller, 1988; Miller, 1998; Miller, 2000; Copeland, Weston \& Shastri, 2005; Miller, 2005; Stulz, 2005; Bolton, 2016; Bolton \& Huang, 2018).

The rest of this paper is structured as follows. Section 2 discusses the demand for finance for sustainable infrastructure. Invariably, these are the required investments in critical infrastructure such as energy, buildings, transport, water, and waste management. The supply of finance for sustainable infrastructure is the focus of section 3. Section 4 attempts to connect the demand and supply sides of finance for sustainable climate-resilient infrastructure. Section 5 describes the considerations for using project finance when implementing clean energy projects or infrastructure instead of on-balance-sheet financing. Section V concludes.

\section{The Demand for Finance for Sustainable Urban Infrastructure}

Global investment in core infrastructure is currently around US\$3.4 trillion per annum. However, to meet human and economic development needs over the coming decades, a total of US\$5 to US\$6 trillion is required each year (Bhattacharya et al., 2016). The annual deficit in infrastructure investment is therefore, above US\$1.5 trillion a year. Seventy percent of the projected investment needs for sustainable infrastructure will be required in emerging and developing countries, with an unusually fast rate of increase in Africa where urban population growth rates are highest (Bhattacharya et al., 2016).

To avoid dangerous levels of climate change and to adapt to existing risks, planned investment must be steered towards lower-carbon, climate-resilient options. For example, Colenbrander et al., 2018 note that:

"the global residential floor area is projected to increase from 164 billion square meters in 2012 to 354 billion square meters in 2050. This new construction must be energy efficient and located in areas with minimal exposure to environmental hazards. One estimate suggests that the total incremental financing needs associated with climate-compatible development are equivalent to around five percent of total investment requirements (Bhattacharya et al., 2016). The higher financing needs reflect the higher capital costs, technological substitution, and technical risks associated with many sustainable infrastructure options."

\subsection{Low-Carbon Urban Development as an Investment Decision}

The Paris Agreement aspires to limit the global temperature rise this century to no more than $1.5^{\circ} \mathrm{C}$ above preindustrial levels. This will require greenhouse gas emissions to reach net zero in the second half of the century, with net negative emissions thereafter (Rogelj et al., 2016). Within the constraints of urban form, investments in five interconnected sectors arguably have the most significant abatement potential. These are:

1. De-carbonizing the electricity grid (energy projects)

2. Energy efficiency in buildings

3. Efficient mobility or transportation systems

4. Water 
5. Waste management

Interventions in these sectors each require a defined set of investment types, which, in turn, need a collection of institutional arrangements to implement. These institutional arrangements are not in place on a systemic basis; otherwise, the required investments would be occurring.

\subsection{Investments in Climate-resilient Urban Development}

Indeed, the more the global temperature increases, the more severe the impacts of climate change. Adaptation investment needs are a function of physical exposure to climate risk and adaptive capacity. Adaptive capacity is in turn, significantly dependent on the level of 'development' of a community, resulting in a continuum of needed interventions. This suggests three broad categories of adaptation, which each require different approaches to financing:

1. Addressing drivers of vulnerability. At the development end of this spectrum, there is a need for investment in basic urban infrastructure and services: sewers, piped water, drains, all-weather roads, waste collection, healthcare, and emergency services. Although an essential part of conventional 'development,' these are critical investments to reduce urban residents' exposure and long term sensitivity to a range of climate risks, such as flooding. These investments need to factor in likely increases in climate impacts.

2. Building response capacity and managing climate risk. All urban infrastructure should be resilient to the impacts of climate change, which may involve additional finance to enhance its robustness, create redundancy, or introduce fail-safe systems (Dodman et al., 2017). Urban planning should also be informed by climate change projections to minimize land development in hazardous areas, such as low-lying coastal zones or floodplains.

3. Confronting climate change. At the adaptation end of this spectrum, there is a need for investment in new infrastructure and services designed specifically to respond to new climate hazards, such as sea-level rise (Bernstein, Gustafson \& Lewis, 2019; Murfin \& Spiegel, 2020), water scarcity and more frequent and intense storms. Relevant measures could include grey, green or blue infrastructure, such as sea walls, emergency warning systems, canals, levee dykes, or green spaces that serve as floodplains -a priority for cities and communities with high physical exposure to climate-related risks.

There is a need for the institutions allocating climate finance to recognize the development-adaptation continuum. Low-income urban residents and cities face everyday risks associated with inadequate necessary infrastructure and poverty, and these risks will be exacerbated rather than necessarily caused by climate change (Pelling et al., 2018). A preoccupation with 'additionality' - the principle that adaptation finance should only be allocated in response to risks that can be explicitly linked to climate change - makes it more difficult to effectively integrate development and adaptation investments.

Therefore, adaptation investment in low-income cities and neighborhoods will require fundamental reforms in political and financial structures to successfully engage with powerful and often entrenched political, economic interests (Chu, Anguelovski, \& Roberts, 2017). Municipal governments need to establish decision-making processes that are accountable and responsive to urban residents who are vulnerable to climate change, such as low-income groups, women, children, the elderly, persons with disabilities, and others. Although there are few documented examples of sustained engagement, there are many promising experiments focused on encouraging public participation and building civic capacities for urban climate adaptation. Where local governments are accountable to their citizens, resourcing and empowering these administrations can reduce vulnerability by enhancing incentives to produce services and infrastructure that meet the SDGs and reduce exposure to climate risk (Colenbrander, Lindfield, Lufkin, \& Quijano, 2018). Fiscal risk must be contained at the same time.

Another challenge concerns balancing risk-return ratios for both development and adaptation investments in urban settings. For instance, recent evidence regarding the crowd funding of 365 clean-tech projects in Europe presents discouraging risk-adjusted return profiles as technology risks contribute to the projects' risk profile (Bento, Gianfrate \& Groppo, 2019). However, there are opportunities to steer private investment towards climate-resilient forms of investment (and deter private investment in mal-adaptation) through information, regulatory or fiscal instruments. Unusually vast opportunities exist concerning:

1. Privately-held infrastructure provides public services, such as transport, electric power networks, water systems, and solid waste. Governments can use regulation and procurement policies to require private constructors and operators to ensure these systems' resilience.

2. Private properties that have a direct incentive to enhance their adaptive capacity, such as downtown buildings could be renovated with green roofs to minimize the urban heat island effect.

3. Insurance and other risk management instruments protect in the event of high-severity, low-frequency events, and can incentivize more climate-compatible behavior.

\section{Supply of Finance for Sustainable Urban Infrastructure}

Although the financing needed to get a project built and running can come from a wide variety of sources, the funding for climate-related and other infrastructure must ultimately come from users and other stakeholders. 
Sometimes national and municipal governments will be able to draw on their funds to finance large infrastructure projects. Still, even cities with relatively large own-sources revenues and access to intergovernmental transfers will generally require additional financing. Cities must carefully examine all options when structuring a project to ensure its financial sustainability over the long term. In this section, we explore possible sources of financing and funding.

\subsection{Domestic Public Finance}

According to Standards \& Poors, government infrastructure investment is equivalent to about three percent of global GDP. Governments have traditionally financed a significant proportion of infrastructure investment, but sourcing sufficient urban infrastructure finance is a challenge. Higher-income countries have reduced infrastructure spending due to various austerity measures and the reprioritization of other public services. Emerging and low-income countries have been increasing their public expenditure on infrastructure, and a large part is directed to urban areas (Bhattacharya et al., 2016). For many governments, spending on infrastructure is constrained by competing priorities and the need to manage existing debt. Larger and more complex projects may also be beyond the capacity of public budgets (with a few notable exceptions, such as China). Additionally, countries that do not pay sufficient attention to fiscal sustainability in the medium term also tend to suffer balance of payments crises and loss of access to private sector financing or credit that can constrain future investment. Balancing near- and long-term financing needs is therefore essential.

The responsibility for funding and financing urban infrastructure has increasingly shifted away from national governments towards municipalities and cities. Inadequate own-source revenues can turn these spending assignments into unfunded mandates. Many local authorities, particularly those in sub-Saharan Africa, have an annual planned budget of less than US\$20 per person, most of which is committed to operating costs, such as salaries. Local revenue collection is often inefficient, and local governments frequently have little or no control over rates or bases at the margin. Opportunities for land-based financing may be constrained by imperfect market information, incomplete or inaccurate land and property registries, and undue influence on the decision-making process by vested interests (Berrisford, Cirolia \& Palmer, 2018). Additionally, a few low- and lower-middleincome countries have the enabling multi-level governance arrangements to equip local authorities to act effectively on climate change. Only 42 percent of countries worldwide are recorded as devolving fiscal or legislative powers to sub-national governments, and of these, the depth of revenue-raising capabilities is highly variable.

\subsection{International Public Finance}

Multilateral, regional and bilateral development organizations can provide significant financing and funding (including grants). Development banks alone have provided up to US\$160 billion for urban infrastructure (Bhattacharya et al., 2016). Many development banks and agencies have committed to ensuring that their investments are compatible with the Paris Agreement. International public climate finance is also projected to play an increasingly prominent role in leveraging and enabling private investment in sustainable infrastructure. Some of this will be distributed through established development banks and agencies. Still, ultimately, the Green Climate Fund (GCF) is intended to be the main channel for mobilizing US $\$ 100$ billion of climate finance by 2020 , of which half is committed to mitigation and half to adaptation. To date, difficulties translating donor pledges to wellcapitalized funds with a viable project pipeline have resulted in a relatively limited impact from multilateral climate funds (Anton, 2020; Nordhaus, 2019).

While national governments may choose to work with these agencies to finance urban infrastructure, few agencies are permitted to work directly with city governments. For example, many climate funds can only allocate resources to central governments or require a sovereign guarantee to allocate resources to sub-national governments. This can constrain city governments' capacity to respond to locally identified priorities in poor coordination or political differences with national agencies. Where development agencies can allocate resources to sub-national governments, local authorities rarely have structural relationships with such bodies and often speak a different technical language. Specialized consultants can supply such information, but cities have limited budgets to commission such expertise. Many donors prefer large-scale projects, which are perceived to have lower transaction costs than small-scale ones. Local governments (particularly in smaller areas) may lack the capacity to implement large-scale projects, absorb large sums of money or leverage co-financing. The lending criteria of many development banks and climate funds indicate a preference for investments in 'hard' infrastructure, such as solar farms and sea walls, rather than 'soft' infrastructure, such as capacity building and raising awareness. "Hard investments" are typically the responsibility of national government agencies, whereas capacity building is the preserve of local organizations. The long lead times and approval processes may further frustrate local efforts to secure international public finance. Therefore, control of climate-related projects and opportunities for capacity development may remain concentrated at the national level.

The GCF and the Adaptation Fund have introduced several relatively new institutional features to channel a 
larger share of climate finance to the local level, including direct access modalities and fit-for-purpose organizational accreditation and project approval processes. These are intended to reduce the transaction costs for local governments and civil society. To date, however, these have been little utilized. As of March 2017, only 36.2 percent of resources committed by the Adaptation Fund and 6.2 percent of those committed by the GCF were released to National Implementing Entities. The balance has been or will be disbursed through International Implementing Entities, such as United Nations agencies, multilateral development banks, international financial institutions, and regional institutions. This suggests that some of the same social, political and economic processes that create and sustain inequalities within a country will be the same processes that determine how adaptation finance is used (Colenbrander et al., 2017). Well-meaning interventions risk consolidating inequality and exclusion by concentrating assets in the hands of a few. Therefore, climate finance architecture risks entrenching differential access to public resources and continuing the political exclusion that contributes to climate vulnerability.

\subsection{Private Finance}

Commercial banks and investment companies manage nearly US\$70 trillion of assets. In contrast, pension funds, insurance companies, and sovereign wealth funds (which tend to have lower risk appetites and longer-term investment horizons) represent nearly US\$44 trillion more (McKinsey, 2016). These investors could be drawn to public infrastructure investments where a sufficient return on investment is forecast based on project income flows, or low-risk government debt repayments based on sensible fiscal sustainability criteria. Bankability and creditworthiness are, therefore, prerequisites to attracting private finance into sustainable urban infrastructure (Floater et al., 2017b). However, these finance sources have not been successfully steered towards climate-positive municipal investments. For example, pension funds remain mostly untapped, with only about one to three percent directed at sustainable infrastructure (Colenbrander, Lindfield, Lufkin, \& Quijano, 2018).

Unpacking the constituent elements within these pools of public, private, and institutional capital is essential, given the different factors such as risk-return expectations and investment horizons of various investor groups. For example, private equity and infrastructure funds seek the highest return and make equity investments in projects with strong growth potential. These funds are often willing to invest in relatively unproven markets and technologies over the medium term (5-15 years). In contrast, pension funds and life insurance companies search for investments that provide predictable income streams to meet long-term obligations such as pensions or insurance claims but need relatively high liquidity to meet demands. Therefore, public capital sources and private investor profiles will suit different types and life-cycle stages of public infrastructure projects. The largest capital pool in terms of assets under management may not necessarily be the most promising source of finance (Floater et al., 2017b). Public finance and development assistance can play an essential role in improving the risk-adjusted returns associated with different infrastructure projects and catalyzing private and institutional sector participation. Table 1: Potential Sources of Private Finance for Sustainable Urban Infrastructure and Barriers faced by each Investor Type

\begin{tabular}{|l|l|l|l|l|l|l|}
\hline $\begin{array}{l}\text { Finance } \\
\text { Source }\end{array}$ & $\begin{array}{l}\text { Kack of } \\
\text { Upfront } \\
\text { Public } \\
\text { Capital }\end{array}$ & $\begin{array}{l}\text { Institutional } \\
\text { Inertia }\end{array}$ & $\begin{array}{l}\text { Institutional } \\
\text { Capacity }\end{array}$ & Risk & Low Returns & $\begin{array}{l}\text { Imperfect } \\
\text { Information }\end{array}$ \\
\hline $\begin{array}{l}\text { Commercial } \\
\text { Investment } \\
\text { Companies }\end{array}$ & & $\begin{array}{l}\text { e.g., National } \\
\text { lending caps } \\
\text { on banks for } \\
\text { infrastructure } \\
\text { financing } \\
\text { (e.g., in India) }\end{array}$ & $\begin{array}{l}\text { e.g., Lack } \\
\text { of } \\
\text { experience } \\
\text { with project } \\
\text { finance and } \\
\text { municipal } \\
\text { bond issues }\end{array}$ & $\begin{array}{l}\text { e.g., } \\
\text { Political } \\
\text { risks and } \\
\text { regulatory } \\
\text { changes that } \\
\text { impact } \\
\text { income } \\
\text { flows } \\
\text { leading } \\
\text { non- } \\
\text { performing } \\
\text { loans }\end{array}$ & $\begin{array}{l}\text { e.g., } \\
\text { capital } \\
\text { requirements } \\
\text { constrain } \\
\text { long term } \\
\text { investments } \\
\text { (e.g., Basel } \\
\text { BiI) }\end{array}$ & $\begin{array}{l}\text { e.g., Lack of } \\
\text { commercial } \\
\text { knowledge in } \\
\text { emerging } \\
\text { markets } \\
\text { loan } \\
\text { syndication }\end{array}$ \\
for \\
\end{tabular}




\begin{tabular}{|c|c|c|c|c|}
\hline & \multicolumn{4}{|l|}{ KEY BARRIERS } \\
\hline $\begin{array}{l}\text { Developers } \\
\text { and } \\
\text { Infrastructure } \\
\text { Operators }\end{array}$ & $\begin{array}{l}\text { e.g., Better } \\
\text { profit-making } \\
\text { opportunities } \\
\text { in servicing } \\
\text { existing assets } \\
\text { than new asset } \\
\text { development }\end{array}$ & $\begin{array}{l}\text { e.g., Local } \\
\text { currency } \\
\text { variability in } \\
\text { project } \\
\text { income } \\
\text { against } \\
\text { foreign } \\
\text { currency- } \\
\text { denominated } \\
\text { debt }\end{array}$ & $\begin{array}{l}\text { e.g., High } \\
\text { local market } \\
\text { interest rates } \\
\text { make projects } \\
\text { unattractive }\end{array}$ & $\begin{array}{l}\text { e.g., Lack of } \\
\text { familiarity with } \\
\text { operating } \\
\text { partners in } \\
\text { emerging } \\
\text { markets }\end{array}$ \\
\hline $\begin{array}{l}\text { Private Equity } \\
\text { and } \\
\text { Infrastructure } \\
\text { Funds }\end{array}$ & $\begin{array}{l}\text { e.g., Investors } \\
\text { lack trusted } \\
\text { relationships } \\
\text { with partners } \\
\text { and } \\
\text { counterparties } \\
\text { in } \quad 3 \mathrm{C} \\
\text { infrastructure }\end{array}$ & $\begin{array}{l}\text { e.g., Risk } \\
\text { that } \\
\text { government } \\
\text { guarantees } \\
\text { could be } \\
\text { reversed }\end{array}$ & $\begin{array}{l}\text { e.g., Private } \\
\text { equity hurdle } \\
\text { rates unsuited } \\
\text { to } \\
\text { infrastructure } \\
\text { investments }\end{array}$ & $\begin{array}{l}\text { e.g., Lack of } \\
\text { information } \\
\text { on the value } \\
\text { potential of } \\
\text { new } \\
\text { technologies }\end{array}$ \\
\hline $\begin{array}{l}\text { Pension Funds } \\
\text { and Insurance }\end{array}$ & $\begin{array}{l}\text { e.g., Appetite } \\
\text { for substantial } \\
\text { investments } \\
\text { may miss } \\
\text { smaller urban- } \\
\text { scale } \\
\text { opportunities }\end{array}$ & & $\begin{array}{l}\text { e.g., Liquidity } \\
\text { requirements } \\
\text { limit long- } \\
\text { term } \\
\text { investments } \\
\text { (e.g., } \\
\text { Solvency II) }\end{array}$ & $\begin{array}{l}\text { e.g., Lack of } \\
\text { knowledge in } \\
\text { infrastructure }\end{array}$ \\
\hline $\begin{array}{l}\text { Sovereign } \\
\text { Wealth Funds }\end{array}$ & $\begin{array}{l}\text { e.g., Fund } \\
\text { prohibitions } \\
\text { from investing } \\
\text { in } \\
\text { infrastructure }\end{array}$ & $\begin{array}{l}\text { e.g., } \\
\text { uncertainty } \\
\text { with asset } \\
\text { performance } \\
\text { in new } \\
\text { technology }\end{array}$ & $\begin{array}{l}\text { e.g., } \\
\text { Numerous } \\
\text { small projects } \\
\text { mismatched } \\
\text { with broad } \\
\text { Capex } \\
\text { strategy }\end{array}$ & $\begin{array}{l}\text { e.g., No clear } \\
\text { partner strategy } \\
\text { in unfamiliar } \\
\text { emerging } \\
\text { markets }\end{array}$ \\
\hline
\end{tabular}

Sources: Adapted from Floater et al. (2017a), Colenbrander, Lindfield, Lufkin, \& Quijano (2018)

\section{Connecting the Demand and Supply Sides}

Financing and funding instruments

There are a few broad categories of financing instruments. Governments have a funding base of taxes, charges, fees, and other revenues, and can additionally use asset-based tools to secure private finance. Equity involves contributing resources in return for a share in the ownership of a project. This typically means that the completed project must be operated as a company of some sort so that the equity can be placed. Debt involves contributing resources in return for repayment, typically on an agreed schedule with interest. Public financing entities may use grants or risk mitigation instruments to reduce the costs or perceived risks to private investors. Under perfect market conditions, the Modigliani-Miller theorem would imply that each financial instrument is as good as another so that there are no net benefits to borrowing. However, in the presence of information, agency, and tax-induced frictions, the financial structure may matter for addressing infrastructural investments. Specific instruments within each of the categories mentioned above are listed in Table 2. 
Table 2. Possible financing and funding mechanisms available to leverage finance from different sources

\begin{tabular}{|c|c|c|c|}
\hline \multirow{2}{*}{$\begin{array}{l}\text { Sources } \\
\text { Finance } \\
\text { Instrument }\end{array}$} & \multirow{2}{*}{$\begin{array}{l}\text { Internal } \\
\text { Domestic public finance }\end{array}$} & \multicolumn{2}{|c|}{ External } \\
\hline & & $\begin{array}{l}\text { International Public } \\
\text { Finance }\end{array}$ & Private Finance \\
\hline $\begin{array}{l}\text { Relevant } \\
\text { institutions }\end{array}$ & $\begin{array}{l}\text {-Federal governments } \\
\text {-National development } \\
\text { banks } \\
\text {-Municipal development } \\
\text { funds } \\
\text {-Sub-national governments }\end{array}$ & $\begin{array}{l}\text {-Multilateral } \\
\text { development banks } \\
\text {-Bilateral development } \\
\text { agencies }\end{array}$ & $\begin{array}{l}\text { - Commercial banks and } \\
\text { investment companies } \\
\text { - Developers and infrastructure } \\
\text { operators } \\
\text { - Private equity and } \\
\text { infrastructure funds } \\
\text { - Pension funds } \\
\text { - Sovereign wealth funds } \\
\text {-Philanthropic foundations } \\
\text {-University endowment funds }\end{array}$ \\
\hline Funding base & $\begin{array}{l}\text { - Intergovernmental fiscal } \\
\text { transfers }\end{array}$ & & $\begin{array}{l}\text {-Property taxes } \\
\text {-Betterment levies or value } \\
\text { capture taxes } \\
\text {-Tax increment financing } \\
\text {-Fees, tariffs and charges }\end{array}$ \\
\hline $\begin{array}{l}\text { Asset-based } \\
\text { instruments }\end{array}$ & $\begin{array}{l}\text { - Sale of land } \\
\text {-Lease of public land assets } \\
\text {-Sale of development rights }\end{array}$ & & -In-kind contributions \\
\hline Debt & $\begin{array}{l}\text {-Specific purpose } \\
\text { concessional loans } \\
\text {-Green Bonds }\end{array}$ & $\begin{array}{l}\text {-Loans } \\
\text { - Concessional loans } \\
\text { - Subordinated debt and } \\
\text { mezzanine loans } \\
\text { - Sukuk and Sharia- } \\
\text { compliant finance }\end{array}$ & $\begin{array}{l}\text { - Bank loans (including } \\
\text { syndicated bank loans) } \\
\text { - Subordinated debt and } \\
\text { mezzanine loans } \\
\text { - Project bonds } \\
\text { - General obligation bonds } \\
\text { - Sukuk and Sharia-compliant } \\
\text { finance } \\
\text { - Securitization and asset-backed } \\
\text { securities } \\
\text {-Crowdfunding }\end{array}$ \\
\hline Equity & & $\begin{array}{l}\text {-Public-private } \\
\text { partnerships } \\
\text { - Project equity } \\
\text { - Yieldcos }\end{array}$ & $\begin{array}{l}\text {-Public-private partnerships } \\
\text { - Project equity } \\
\text {-Listed infrastructure corporates } \\
\text { and funds } \\
\text { - Preferred shares } \\
\text { - Yieldcos } \\
\text { - Trusts } \\
\text {-Co-investment platforms } \\
\text {-Crowdfunding }\end{array}$ \\
\hline Grants & - Specific purpose grants & - Grants & -Philanthropic grants \\
\hline $\begin{array}{l}\text { Risk Mitigation } \\
\text { Instruments }\end{array}$ & $\begin{array}{l}\text { - Credit guarantee } \\
\text { - Credit insurance }\end{array}$ & $\begin{array}{l}\text { - Credit guarantee } \\
\text { - Credit insurance }\end{array}$ & $\begin{array}{l}\text { - Business insurance } \\
\text { - Credit insurance }\end{array}$ \\
\hline
\end{tabular}

Source: Modified from Colenbrander, Lindfield, Lufkin, \& Quijano (2018)

There is scope to use or adapt many of these financing instruments for specifically green or climate purposes. In equity-based financing, the financing instruments are listed shares, equity-based crowd funding, private equity, venture capital, joint-venture or co-investment platforms, project equity, and public-private partnerships. Some of these instruments are not necessarily mutually exclusive, as equity-based financing may be a combination of these. Venture capital (VC) and private equity (PE) investment in renewable energy, for instance, rose to USD \$3 billion in 2019 , its highest since 2015 but less than a third of its peak since 2008 . VC/PE investment in solar rose "to $\$ 1.8$ billion, and more than doubled to $\$ 529$ million for wind, while falling just over a third to \$396 million for biofuels (UNEP/BNEF, 2020)." Most of the largest deals were equity injections into project development companies. Table 3 below describes the trend of global venture capital (VC) and private equity (PE) financing for 2005-2019. 
The other components of equity green financing are not yet disclosed, and so cannot be reported here.

Table 3: VC and PE New Investment in Renewable Energy, \$'B (2005-2019)

\begin{tabular}{|l|l|l|l|l|l|l|l|l|l|l|l|l|l|l|l|}
\hline & 2005 & 2006 & 2007 & 2008 & 2009 & 2010 & 2011 & 2012 & 2013 & 2014 & 2015 & 2016 & 2017 & 2018 & 2019 \\
\hline $\begin{array}{l}\text { VC/ PE } \\
\text { (\$'B) }\end{array}$ & 1.6 & 4.1 & 5.6 & 9.9 & 4.6 & 8.0 & 5.0 & 4.0 & 2.1 & 2.7 & 3.2 & 2.4 & 1.5 & 2.4 & 3.0 \\
\hline $\begin{array}{l}\text { GROWTH } \\
(\%)\end{array}$ & $129 \%$ & $156 \%$ & $37 \%$ & $77 \%$ & $-54 \%$ & $74 \%$ & $-38 \%$ & $-20 \%$ & $-48 \%$ & $29 \%$ & $19 \%$ & $-25 \%$ & $-38 \%$ & $60 \%$ & $25 \%$ \\
\hline
\end{tabular}

Sources: UNEP, Frankfurt-School UNEP-Centre, BloombergNEF

According to the Climate Bond Initiative, in debt-based financing, the total value of 'green bonds' is as of December 2019 was USD257.7bn up by 51 percent from the 2018 figure of USD170.6bn. The 2019 volume was largely driven by the European market, which accounted for $45 \%$ of global issuance. Asia-Pacific and North America accounted for $25 \%$ and $23 \%$, respectively. Such green bonds may be tied to specific, environmentally positive projects such as public transport, renewable energy, or solid waste management. This is what is commonly referred to as project finance or off-balance-sheet financing (OBSF). Alternatively, governments may issue general obligation green bonds (as the cities of Johannesburg, Mexico City, and Ottawa have done) raise financing for environmental projects without clear revenue streams, including adaptation initiatives (also referred to as onbalance sheet financing). Similarly, fees, taxes, and charges may be designed to steer investment towards climatecompatible forms of urban development. Carbon pricing is definitely the most economically efficient way to accelerate a low-carbon transition (Stiglitz et al., 2017). Otherwise, the design of land/property taxes or additional interventions such as congestion pricing can be used to incentivize more carbon-efficient modes of urban growth. Development financing institutions already widely use risk mitigation instruments and grants to crowd in private investment for low-carbon infrastructure projects, but this could be accelerated and scaled (Bhattacharya et al., 2016). Out of the diversity of mechanisms set out in Table 2, some have particular promise to support investment in sustainable urban infrastructure at scale (Floater et al., 2017a). Table 4 below presents a list of national securities markets with a dedicated green bond section. As of the end of December 2019, there were 18 such Exchanges around the world.

Table 4: Stock Exchanges with Dedicated Green Bond Section

\begin{tabular}{|l|l|l|l|}
\hline S/N & Name of Stock Exchange & Type of Dedicated Section & Launch Date \\
\hline 1 & Oslo Stock Exchange & Green Bonds & January 2015 \\
\hline 2 & Stockholm Stock Exchange & Sustainable Bonds & June 2015 \\
\hline 3 & London Stock Exchange & Green Bonds & July 2015 \\
\hline 4 & Shanghai Stock Exchange & Green Bonds & March 2016 \\
\hline 5 & Mexico Stock Exchange & Green Bonds & August 2016 \\
\hline 6 & Luxembourg Stock Exchange & Luxembourg Green Exchange & September 2016 \\
\hline 7 & Borsa Italiana & Green and Social Bonds & March 2017 \\
\hline 8 & Taipei Exchange & Green Bonds & May 2017 \\
\hline 9 & Johannesburg Stock Exchange & Green Bonds & October 2017 \\
\hline 10 & Japan Exchange Group & Green and Social Bonds & January 2018 \\
\hline 11 & Vienna Exchange & Green and Social Bonds & March 2018 \\
\hline 12 & Nasdaq Helsinki & Sustainable Bonds & May 2018 \\
\hline 13 & Nasdaq Copenhagen & Sustainable Bonds & May 2018 \\
\hline 14 & Nasdaq Baltic & Sustainable Bonds & May 2018 \\
\hline 15 & The International Stock Exchange & Green Bonds & November 2018 \\
\hline 16 & Frankfurt Stock Exchange & Green Bonds & August 2019 \\
\hline 17 & Moscow Exchange & Sustainable Bonds & November 2019 \\
\hline 18 & Euronext & Green Bonds &
\end{tabular}

Source: Climate Bonds Initiative 
Table 5. Global Trends in Renewable Energy Investment 2020 Data Table, \$ BN

\begin{tabular}{|c|c|c|c|c|c|c|c|c|c|c|c|c|}
\hline & 2004 & 2010 & 2011 & 2012 & 2013 & 2014 & 2015 & 2016 & 2017 & 2018 & 2019 & CAGR \\
\hline & $\$$ 'B & $\$$ S'B $^{\prime}$ & $\$ ' B$ & $\$$ 'B & \$'B & $\$ ' B$ & $\$$ & $\$ ' B$ & \$'B & $\${ }^{\prime} \mathrm{B}$ & \$'B & \\
\hline New Investment & 44.8 & 238.5 & 286.6 & 253.7 & 231.7 & 288.1 & 317.3 & 293.9 & 331.4 & 296.0 & 301.7 & $15 \%$ \\
\hline \multicolumn{13}{|l|}{ By Sector } \\
\hline Wind & 18.4 & 97.8 & 83.3 & 78.3 & 83.3 & 111.1 & 119.7 & 123.5 & 133.4 & 132.7 & 142.7 & $15 \%$ \\
\hline Solar & 10.7 & 102.0 & 160.1 & 144.0 & 120.4 & 147.8 & 176.6 & 145.9 & 180.8 & 143.5 & 141.0 & $19 \%$ \\
\hline Bio-fuels & 3.9 & 10.1 & 10.5 & 7.7 & 5.1 & 5.5 & 3.6 & 2.1 & 3.3 & 3.3 & 3.0 & $-2 \%$ \\
\hline $\begin{array}{l}\text { Biomass and w-t- } \\
\text { e }\end{array}$ & 7.9 & 17.3 & 20.9 & 15.4 & 14.6 & 13.1 & 10.4 & 15.2 & 7.4 & 11.5 & 11.2 & $2 \%$ \\
\hline Small hydro & 2.8 & 8.2 & 7.7 & 6.3 & 5.7 & 7.4 & 4.2 & 4.3 & 4.0 & 2.3 & 2.5 & $-1 \%$ \\
\hline Geothermal & 1.1 & 2.8 & 3.8 & 1.7 & 2.4 & 2.9 & 2.5 & 2.7 & 2.4 & 2.5 & 1.2 & $1 \%$ \\
\hline Marine & 0.0 & 0.3 & 0.3 & 0.3 & 0.2 & 0.4 & 0.2 & 0.2 & 0.2 & 0.2 & 0.2 & $12 \%$ \\
\hline TOTAL & 44.8 & 238.5 & 286.6 & 253.7 & 231.7 & 288.1 & 317.3 & 293.9 & 331.4 & 296.0 & 301.7 & $14 \%$ \\
\hline \multicolumn{13}{|l|}{ By Geography } \\
\hline United States & 6.0 & 34.6 & 50.3 & 40.7 & 36.1 & 38.4 & 46.9 & 44.4 & 48.6 & 47.1 & 59.0 & $16 \%$ \\
\hline Brazil & 0.7 & 7.2 & 10.2 & 7.8 & 3.9 & 7.7 & 6.4 & 5.7 & 6.2 & 3.8 & 6.8 & $16 \%$ \\
\hline $\begin{array}{l}\begin{array}{l}\text { AMERICAS } \\
\text { (Excl. US } \quad \& \\
\text { Brazil) }\end{array} \\
\end{array}$ & 1.7 & 12.0 & 9.8 & 10.4 & 12.5 & 15.2 & 11.5 & 6.5 & 13.2 & 10.7 & 12.8 & $14 \%$ \\
\hline Europe & 23.3 & 112.2 & 131.7 & 91.1 & 57.7 & 68.7 & 61.1 & 71.5 & 49.1 & 60.8 & 58.4 & $6 \%$ \\
\hline $\begin{array}{ll}\text { Middle } & \text { East } \\
\text { \&Africa } & \\
\end{array}$ & 0.6 & 4.0 & 3.1 & 9.9 & 7.2 & 8.4 & 11.6 & 7.1 & 10.7 & 16.5 & 15.4 & $24 \%$ \\
\hline China & 3.0 & 42.4 & 45.7 & 56.6 & 63.4 & 88.7 & 121.1 & 105.6 & 148.4 & 95.9 & 90.1 & $25 \%$ \\
\hline India & 2.7 & 7.7 & 12.4 & 6.7 & 5.0 & 7.4 & 8.0 & 12.5 & 13.7 & 11.6 & 11.2 & $10 \%$ \\
\hline $\begin{array}{ll}\text { Asia \&Oceania } \\
\text { (Excl. China \& } \\
\text { India) }\end{array}$ & 6.7 & 18.5 & 23.5 & 30.4 & 45.8 & 53.7 & 50.6 & 40.7 & 41.6 & 49.6 & 48.2 & $14 \%$ \\
\hline TOTAL & 44.8 & 238.5 & 286.6 & 253.7 & 231.7 & 288.1 & 317.3 & 293.9 & 331.4 & 296.0 & 301.7 & $14 \%$ \\
\hline
\end{tabular}

Source: UNEP, Frankfurt School-UNEP Centre, BloombergNEF

New investment volume adjusts for re-invested equity. Total values include estimates for undisclosed deals.

Pricing, regulation, and standards can drive investments into sustainable urban infrastructure. Economic efficiency highlights the advantages of a typical global carbon price, with emissions reductions occurring wherever the marginal costs are lowest. By 2017, 42 national and 25 sub-national jurisdictions were pricing carbon (Stiglitz et al., 2017). In the absence of a carbon price or where additional externalities must be considered (such as air pollution or technological learning), other pricing schemes can further spur investment. For example, incentives for electric cars and rooftop photovoltaic panels have played a significant role in growing those in China and Europe (Shive \& Forster, 2020).

Regulatory measures are particularly robust for creating a shift from infrastructure investment locking in high-carbon pathways to new green technologies in the urban economy. Policies regarding the entry, treatment, and protection of different investors are essential to creating an enabling environment. Still, financial regulation can go further to encourage or mandate investment in green projects. Governments can also regulate developers and operators (such as utilities) to invest in climate-compatible options preferentially. Renewable energy portfolio standards, for instance, can mandate that services provide a certain fraction of renewable energy, which increases investors' certainty about the size and value of future markets. Minimum energy performance standards or voluntary labeling codes for appliances, buildings, lighting, and vehicles can encourage businesses and households to choose more efficient options.

Governments can:

1) Create efficient and effective regulatory frameworks and standards that steer investment in sustainable infrastructure projects and investments. This is particularly important in sectors characterized by small investment sizes. Consumer choices are key investment drivers, such as energy efficiency, distributed energy, non-motorized and electric mobility, shared mobility, and green buildings.

2) Work with commercial banks, banking regulators, and capital market authorities on green finance voluntary practices and mandatory measures, including new market and finance product development, environmental impact reporting, and green secondary market rules.

3) Establish pricing systems (whether negative pricing, such as emission trading schemes, or favorable pricing, such as feed-in tariffs) to steer investment into sustainable infrastructure investments. Again, this is particularly important in sectors where firm and household choices are key investment drivers, or viable infrastructure options have higher costs than conventional options without government intervention.

Debt financing is an essential tool for raising upfront capital to finance sustainable urban infrastructure. Debt capital can be raised in the form of a bank loan, syndicated loans (with multiple lenders), or bonds. In most 
countries, bank lending tends to predominate early in a city's financial development with bond transactions emerging later (although bank lending will likely continue catering to different elements of the market). This trend is explained by the generally lower transaction costs and complexity associated with bank lending compared to bonds. Loans can be further differentiated between short-term 'project finance' used to pay the cost of project construction, and longer-term 'permanent finance' used to support assets during their operational life. Permanent finance typically has lower interest rates as the risks are more predictable than for project finance. Labeling and standards can also ensure that debt finance is used for green investments, which are typically cost-effective for the issuer (Steffen, 2018, Colenbrander, Lindfield, Lufkin, \& Quijano, 2018).

Debt financing may be secured at the national or city level. As a prerequisite to debt financing, governments need budgetary, accounting and financial management capabilities, and sufficient funding sources for making repayments. This is a significant constraint for urban infrastructure in low-income countries. Users may be unwilling or unable to pay high enough charges to allow full cost recovery plus a return on investment. Assetbacked securities can also reduce the risk for private and institutional investors but could shift liabilities to the central government. Even when a city has achieved an investment-grade credit rating, sound financial management is essential to minimize the risk of future default and provide headroom for future investments. At the same time, debt repayments of older projects are still ongoing. In the absence of fiscal decentralization or as a complement to municipal debt financing, creditworthy national governments can collaborate with cities in identifying investment priorities, structure bankable projects, or domestic bond issues to support them.

Governments can facilitate debt financing by:

1) Reforming national regulations to allow local borrowing and clarify the conditions for bank lending or bond issuance. This could include liberalizing regulations dictating whether cities (and utilities) can borrow and how much, borrowing procedures, whether they can borrow in a group, what currencies they can borrow in, the type of collateral that they may pledge to secure borrowing, and action in cases of default.

2) Building the capacity of sub-national governments to improve budgetary planning, accounting, and financial management in local governments. This can reduce the costs of borrowing either through bank lending or bond issuance. They could also help to build local governments' experience with borrowing through joint projects or credit guarantees.

3) Developing project pipelines, either via national borrowing or with support for project preparation. This could include the use of pooling instruments to aggregate similar small projects, such as a national fund for energy efficiency, decentralized renewable and other same-type infrastructure investments across secondary and tertiary cities.

4) Participating in programs focused on enhancing (municipal) creditworthiness, e.g., those run by Climate KIC and the World Bank. They could also promote standards and labeling to encourage preferential issuance of green bonds at both the national and sub-national levels.

Land value capture (LVC) includes a range of instruments by which the public sector can capture a proportion of rising land prices to fund sizeable urban infrastructure projects. Investments in water, sanitation, and transport infrastructure can lead to increased land and property values nearby. This uplift in value can be used as a source of revenue. At the same time, land-based financing can be used to drive more compact urban development.

The effectiveness of LVC can be increased where governments integrate spatial planning policies and infrastructure investment strategies. This can underpin nodes and corridors of managed urban growth, enhancing land values within proximity. A transparent land and property market and an effective tax system can further improve land value capture approaches. National governments can provide robust regulatory frameworks and guarantees that enable municipalities to capture land value uplifts, though cities will need significant technical capacities for successful implementation. Where land is owned by national agencies (as in China or Ethiopia), they can directly influence or capture the gain related to land sales or ground leases.

Governments can facilitate more extensive deployment of LVC instruments through:

1) Developing national LVC regulatory frameworks that outline whether cities can sell and trade development rights, land leasing systems, and the rules governing rights exchanges. They could additionally create best practice guidance for local co-investment based on local-level LVC.

2) Coordinating spatial plans and infrastructure strategies across different scales and align them with LVC mechanisms.

3) Investing in more efficient property markets, for example, by systematizing valuation practices, registration and titling, and introducing transparent transaction registries. This also creates opportunities to improve public land and built asset registries and condition assessments to determine where there are investment potential and uncaptured value in government holdings.

4) Multilevel collaboration to identify projects suited to LVC (recognizing there are several specific LVC instruments available with different finance raising/repayment characteristics) and identify bridge financing sources (for example, concessional finance from development finance institutions) if needed so 
that projects can be initiated in advance of LVC revenue flows.

Public-private partnerships (PPPs) are contracts that allocate risks between public and private entities and often play a role in which governments face technical, institutional, and financial constraints (UNCTAD, 2013). There are many forms of PPP, but their potential is typically limited to projects that involve commercial returns on revenue-generating assets. Energy and road infrastructure projects have attracted the vast majority of global PPP finance, subject to market regulations, and thanks to clear income streams from these assets (ibid.).

PPPs are complex structures. Asymmetric information between government levels and between the public and private partners can lead to rent-seeking behavior. Without tight monitoring and public expenditure management, PPPs can effectively create hidden liabilities for government agencies. Therefore, PPPs are a particularly important instrument in middle and high-income countries with sophisticated financial systems. The effectiveness of this mechanism depends heavily on appropriate project identification, structuring, contractual arrangements, and government capacity.

Governments can enable greater use of PPPs through:

1) Evaluating the asset types and prospective investments that are suited to PPPs and contribute to sustainable urban form and infrastructure development. This can be used to prepare a long list of feasible pilot or exemplar projects.

2) Establishing regulation and legislation outlining the ability of cities/utilities to enter into PPP transactions, and detailing the corporate framework for entities which may be established to do so, the way in which tariffs are set, and the mandate of regulatory oversight processes and agencies.

3) Establishing national PPP units that can support project preparation and tendering, drawing on international technical assistance as required to ensure the feasibility, accountability, transparency and competitiveness of the process.

5.0 Factors Determining Choice of Off-Balance Sheet Financing versus On-Balance Sheet Financing: A Financetheoretic Approach

The classical way to finance new projects is to utilize the cash flows generated from the assets on the balance sheet of the project sponsor. However, there are circumstances where such on-balance-sheet financing approach may be sub-optimal so that off-balance sheet financing where repayment of finance is tied to the specific project cash flows may be more appropriate. The OECD (2016) outlines the possible factors influencing the funding and financing models such as:

i. The financing profile of the investment wherein a substantial initial investment may be followed by high operating and maintenance costs;

ii. The potential for cost recovery from users may be low thus necessitating public spending; difficulty in specifying and monitoring quality in project execution;

iii. High degree of uncertainty and unstable policy frameworks; financial market conditions may favor either onbalance-sheet or off-balance-sheet financing;

iv. Optimal allocation of risks.

Steffen (2018) provides a capstone. The following factors are vital considerations for considering project finance:

\subsection{Negative Financial Synergies with existing business}

When companies are embarking on renewable energy projects, for instance, synergies with their existing business are a vital concern. While operating synergies (resulting from economies of scale) may be positive, financial synergies are usually negative for the following reasons:

1. Contamination risk: The business risk associated with the contemplated projects may be higher than the risk of the existing business. If projects are added to the current investments of a sponsor, they become part of the business's risk-return profile. Assets and cash flows from the existing business serve as a guarantee for additional lending used to finance the project. Thus, poor project performance can severely affect the current transaction, increasing the bankruptcy risk of the core firm, especially if the project is large compared to the existing business. The financial theory implies that companies should not be concerned about idiosyncratic bankruptcy risk in perfect markets as portfolios are diversified at the shareholder level (Sharpe, 1964). In real markets, though, bankruptcies come with irreversible costs, and managers are risk-averse, so bankruptcy risk matters. Realizing the project in a separate entity via project finance can preserve the existing business from contamination and thereby reduce financing cost for the core firm - the textbook reason for using project finance. The effect is especially likely to occur if the new project comes with high investment compared to the existing balancing sheet and if its cash flows are risky and correlated with the current business. Capital-intense power plant projects can meet these characteristics. Thus, in cases where contamination risk motivates project finance, it will be used for power plant projects with specific characteristics, namely significant and high financial risk (i.e., the risk 
of a financial loss for project investors).

2. Debt overhang. When projects are financed through equity and debt on the sponsor's balance sheet, the ability to finance new projects will depend on the strength of that balance sheet. It can be limited if its debt ratio is already high, especially if many new projects are planned in a row. High leverage is typically associated with the absence of financial flexibility, which may bypass valuable energy-efficient investments - the familiar under-investment problem attributable to Myers (1977). Stulz and Johnson (1985) show that profitable projects might not be undertaken in such situations. Still, the availability of secured debt helps to realize them by providing additional security beyond the general recourse on the balance sheet (quoted in Steffen, 2018). Following the same rationale, project or off-balance sheet finance is an even more effective instrument to finance such projects. It decouples the project entirely from the sponsor's balance sheet. In line with this argument, project finance allows a sponsor to realize projects that are otherwise unviable and "potentially allows that sponsor to choose a higher debt ratio for the project than feasible under corporate finance, creating value through higher tax shields"(Esty, 2003). In the power sector, some companies specifically focus on developing new power plants, extending their cumulative investment rapidly.

3. Securitization: As a result, to point one above, it is also possible that contemplated projects embody lower business risks relative to the existing business portfolio. Bundling the project as a single contract could enable the project sponsor to obtain funding at a lower cost of capital than the company's cost of capital because of the project's lower project risk. The potentially high cost of capital conundrum may hinder the development of clean-tech projects in the power or energy sector. That way, off-balance sheet finance can be a remedy. Thus, in cases where securitization motivates project finance, it will be used in specific combinations of a project- and sponsor characteristics, namely for low-risk projects conducted by "highrisk players" such as distressed utilities.

Beyond motivating the use of "classical" project finance on the debt side, it is worth noting that the securitization motive also explains the recent emergence of the yieldco model on the equity side (mainly in the US). Sponsors, often large utilities or independent power producers with a mix of renewable and conventional generation assets create a yieldco by carving out renewable energy plants with stable cash flows and low financial risks into a separate, publicly-traded corporation, thus attracting equity investors as minority shareholders (Verdability, 2020). Beyond U.S.-specific tax considerations, a key reason for choosing the yieldco model is to "replace high-cost capital with lower-cost capital," if the financial risk of operational solar and onshore wind plants is much lower than the sponsors' core business activities"(Verdability,2020).

\subsection{Market Imperfections}

Finance theory guides how off-balance-sheet financing can help address market imperfections resulting from information asymmetry and agency conflicts.

1. Information asymmetry between sponsor and lenders/financiers. A company realizing a project always has better information about its prospect and actual performance than outside financiers. Myers \& Majluf (1984) analyze how information asymmetry between corporate managers and outside investors lead to a financing pecking order. The oldest economic explanation for project finance considers it a tool to reduce these asymmetries by allowing lenders better to distinguish project performance from the general firm performance. In their classical paper, Shah and Thakor (1987) postulate that it can be advantageous to use project finance instead of revealing costly information about the firm. That would provide a comparable level of transparency - especially for risky projects, which require a high level of scrutiny that consequently has to be applied to the project only (quoted in Steffen, 2018). Thus, if the information asymmetry between sponsor and lenders motivates the use of project finance, it will be used, especially for risky power plant projects.

2. Agency conflicts between project owners and contractual parties. Projects like power plants depend on a nexus of contractual relationships with different parties such as a fuel supplier and the electricity off-taker. If bilateral monopolies characterize these relationships, parties might opportunistically threaten the project to realize better conditions after completion (the "hold up" problem). Project finance with a carefully-crafted set of non-financial long-term contracts and joint vertical ownership can mitigate these agency conflicts. A different agency conflict potentially occurs with host governments, who might pursue measures leading to creeping expropriation after infrastructure assets such as a power plant are completed. Project finance can mitigate such risks by allowing for a high debt ratio and syndication of debt that improves the ex-post bargaining position of project owners. It also opens the way to include international financial institutions such as the World Bank's IFC into the asset-specific financial structure, which provides a "political umbrella" to deter creeping expropriation.

3. Agency conflicts between project owners and managers. Corporate managers' interests are not necessarily aligned with that of business owners' (Jensen \& Meckling, 1986), especially in companies with high free cash flows (such as capital-intensive power plants). Managers might prevent the payout of cash to shareholders and 
instead maintain the resources under their control by pursuing value-destructing re-investments or engaging in a glamorous corporate lifestyle (Jensen, 1986). Using project finance allows us to set up a tight project-specific governance structure and implement a very high debt ratio to discipline managers (Jensen, 1986). Such a "disciplining" effect would be most useful in projects with high upfront investment and low operating costs. Thus, if agency conflicts between owners and managers motivate the use of project finance, it will be used primarily in power plant projects with this characteristic, i.e., with a high CAPEX to OPEX ratio.

\subsection{Considerations Regarding Organizational Structure}

Project finance is amenable to organizational structures that are advantageous from a company's viewpoint.

1. Permits horizontal joint-ventures: Structuring a project as a non-recourse separate entity from the sponsor's business facilitates its realization as a vertical joint venture. However, projects such as power plants can also be realized as horizontal joint ventures between companies at the same levels of the value chain. These include utilities based on the strategic advantage of organizational knowledge implicit in the operation of a technology. 2. Independence of civic or mandatory project: Lastly, low-carbon energy technologies could be considered as social investments. Some retail investors (such as citizens in a community where a wind farm or solar plant is considered) have been shown to take welfare aspects into account for investment decisions (Shive \& Forster, 2020) beyond the traditional risk-return consideration. Bolton \& Kacperczyk (2020) investigate whether carbon emissions influence the cross-section of US stock returns such that investors demand higher yields from holding stocks of companies with higher total carbon dioxide emissions after controlling for book-to-market, size, momentum and other factors that predict returns in the asset pricing literature. Bolton \& Kacperczyk (2020) further find that institutional investors exhibit strict exclusionary screening based on direct emission intensity, implying that ethical investing is not a fluke.

\section{Conclusion}

This paper has attempted a review of the demand and supply sides for financing urban infrastructure to address risks posed by climate change. The demand for finance side encompasses the agencies undertaking projects, the type of projects, and the funding required to repay finance (project finance vs. on-balance sheet finance). The supply side of finance maps possible investors and their likely risk appetites, return expectations, liquidity needs, and time horizons. Next, the financing and funding mechanisms that can be deployed on the demand side to raise and steer finance from the supply side and integrate climate considerations into the project preparation process were reviewed. The factors that determine the suitability of project finance, also known as off-balance-sheet financing in implementing renewable energy projects, were discussed. They include the possibility of adverse financial synergies, market imperfection arguments; and organizational structure considerations.

Helping policymakers mobilize private investment in renewable energy projects and other critical infrastructure requires addressing outstanding policy and market obstacles to such investment. Policy priorities for addressing fragmentation issues in energy markets and suggested ways for international support include: overcoming financing challenges and mobilizing private finance for renewable energy, setting coherent and robust climate mitigation policies and aligning the investment environment, and improving data collection (OECD, 2016).

There exists sufficient fertile ground for incorporating the analytical frameworks from corporate finance into the climate-economy literature, especially the interaction of investment (demand side) and financing decisions in bridging the infrastructural financing gap around the world. Mandatory projects may not yield positive net present values (NPV) to modern corporations. The incorporation of real options analysis of the climate viability of such projects via assessment of social benefits and accrued prestige to "environmentally compliant" corporations means that infrastructural projects can be appraised on financially acceptable grounds, especially in a public-private partnership (PPP) arrangement of urban infrastructure provision. As usual, the financing of such projects will be driven by the capacity to map possible institutional investors and their likely risk appetites, return expectations, liquidity needs, and their time horizons (Dyck, Lins, Roth \& Wagner, 2019; Krueger, Sauter \& Starks, 2020).

The asset pricing implications of climate risks can be studied by examining the transmission of risks to the prices of the underlying securities issued by the companies most affected by specific climate conditions. Bolton \& Kacperczyk (2020) provide evidence that institutional investors shy away from companies with high $\mathrm{CO}_{2}$ emissions and demand a carbon premium if they must invest in such companies. Painter (2020) also provides evidence that municipal bonds embody climate change risks over the long term as rating agencies incorporate climate resilience measures into municipal bond ratings.

Fertile grounds for future research exist and include the following: Strengthening the economic and financial case for climate-compatible urban development from the perspective of a range of different actors (including diverse investors); understanding the spatial allocation of productive assets, households, and jobs relative to climate risk; assessing the different ways that urban financial systems could enhance inclusion and equity and thereby reduce vulnerability to climate change; determining best practice in engaging private actors in sustainable urban infrastructure projects of different kinds and articulating the conditions or contingencies for success; 
accounting for flows of climate finance and improving the use of international public finance to achieve paradigmshifting potential.

\section{References}

Aglietta, M. \& Espagne, E.(2016), "Climate and finance systemic risks, more than an analogy? The Climate Fragility Hypothesis", CEPII Working Paper

Aleluia, J. \& Ferrão, P. (2017), Assessing the Costs of Municipal Solid Waste Treatment Technologies In Developing Asian Countries, Waste Management, 69:592-608.

Alok, S., Kumar, N. \& Wermers, R. (2020), Do Fund Managers Misestimate Climatic Disaster Risk? Review of Financial Studies, 33(3): 1146-1183

Andersson, M., Bolton, P. \& Samana, F. (2016), Hedging Climate Risk, Financial Analysts Journal, 72(3): 13-32

Anton, A. (2020) Taxing Crude Oil: A Financing Alternative to Mitigate Climate Change, Energy Policy, 136: 111031

Baldauf, M., Garlappi, L \& Yannelis, C. (2020), Does Climate Change Affect Real Estate Prices? Only If You Believe In It, Review of Financial Studies, 33(3): 1256-1295

Bansal, R., Ochoa, M., \& Kiku, D. (2016), Climate Change and Growth Risks, Working Paper, National Bureau of Economic Research, wp23009

Barnett, M., Brock, W. \& Hansen, L.P. (2020), Pricing Uncertainty Induced by Climate Change, Review of Financial Studies, 33(3): 1024-1066

Barro, R.J., (2015), Environmental Protection, Rare Disasters and Discount Rates, Economica,82: 1-23

Battiston, S., Mandel, A., Monasterolo, I., Schutze, F. \& Visentin, G. (2017), "A Climate Stress-Test of The Financial System," Nature Climate Change, 7: 283-288.

Bento N., Gianfrate G. \& Groppo S.V. (2019), "Do Crowdfunding Returns Reward Risks? Evidences from Cleantech Projects," Technological Forecasting \& Social Change,141: 107-116. DOI: 10.1016/j.techfore.2018.07.007.

Bernstein, A., Gustafson, M. \& Lewis, R. (2019), Disaster on the Horizon: The Price Effect of Sea-level Rise, Journal of Financial Economics, 134(2): 253-272

Berrisford, S., Cirolia, L.R., \& Palmer, I. (2018), Land-based Financing in sub-Saharan African cities, Environment and Urbanization, 30(1): 35-52

Bhattacharya, A, Meltzer, JP, Oppenheim, J, Qureshi, Z. \& Stern, N. (2016), "Delivering on Sustainable Infrastructure for Better Development and Better Climate" Brookings Institute, New Climate Economy and the Grantham Institute for Climate Change and the Environment, London and Washington DC. Available at: www.brookings.edu/wp-content/uploads/2016/12/global 122316 delivering-on-sustainableinfrastructure.pdf

Bolton, P. (2016), Debt and money: Financial Constraints and Sovereign Finance, Journal of Finance 71(4): 14831510.

Bolton, P. \& Huang, H. (2018), The Capital Structure of Nations, Review of Finance, 22(1):45-82

Bolton, P. \& Kacperczyk, M. (2020), Do Investors Care About Carbon Risk? NBER Working Paper 26968 Brennan, M. \& Zhang, Y. (2020), Capital Asset Pricing with A Stochastic Horizon, Journal of Financial and Quantitative Analysis, 55(3): 783-827

Campbell, S. D., \& Diebold, F. X. (2005) Weather Forecasting for Weather Derivatives, Journal of the American Statistical Association, 100: 6-16.

Carhart, M. M. (1997), On Persistence of Mutual Fund Performance, Journal of Finance 52(1):57-82

Chu, E, Anguelovski, I \& Roberts D (2017), Climate Adaptation as Strategic Urbanism: Assessing Opportunities and Uncertainties for Equity and Inclusive Development in Cities, Cities, 60(A) 378-387

Climate Bonds Initiative (2018), 2017 Policy Highlights, Review and Forecast for 2018 See www.climatebonds.net/files/files/CBI-PolicyRoundup_2017\%20Final\%203.pdf

Colenbrander, S., Gouldson, A., Roy, J., Kerr, N., Sarkar, S., Hall, S., Sudmant, A., Ghatak, A.,Chakravarty, D., Ganguly, D., \& McAnulla, F. (2016), Can Low-Carbon Urban Development Be Pro-Poor? The case of Kolkata India, Environment and Urbanization 29(1): 139-158.

Choi, D., Gao, Z. \& Jiang, W. (2020), Attention to Global Warming, Review of Financial Studies, 33(3): $1112-$ 1145 .

Colenbrander, S., Lindfield, M., Lufkin, J. \& Quijano, N. (2018), Financing Low-Carbon Climate-Resilient Cities, Coalition for Urban Transitions, London and Washington DC

Colenbrander, S., Dodman, D., \& Mitlin, D (2018), Using Climate Finance to Advance Climate Justice: The Politics and Practice of Channeling Resources to the Local Level. Climate Policy, Forthcoming.

Copeland, T. E., Weston, J. F., \& Shastri, K. (2005), Financial Theory and Corporate Policy, 4th Edition, Boston, MA: Pearson Addison-Wesley.

Daniel, K. D., Litterman, R. B., \& Wagner, G. (2018), Applying Asset Pricing Theory to Calibrate the Price of 
Climate Risk, National Bureau of Economic Research, Working Paper http://www.nber.org/papers/w22795.

Dell, M., Jones, B. F., \& Olken, B. A., (2014), What Do We Learn From The Weather? The New Climate-Economy Literature, Journal of Economic Literature, 52(3): 740-798

Deschenes, O., \& Greenstone, M. (2007), The Economic Impact Of Climate Change: Evidence from Agricultural Output and Random Fluctuations in Weather, American Economic Review, 97(1): 354-385

Dodman, D., Diep, L., \& Colenbrander, S. (2017), Resilience and Resource Efficiency in Cities. UN Environment, Nairobi, Kenya, Available

at: https://wedocs.unep.org/bitstream/handle/20.500.11822/20629/Resilienceresource_efficiency_cities.pdf?seq uence $=1 \&$ is Allowed $=y$

Dyck, A., Lins, K. V., Roth, L., \& Wagner, H. F. (2019), "Do Institutional Investors Drive Corporate Social Responsibility? International Evidence,” Journal of Financial Economics 131(3): 693-714.

Esty, B. C. (2003), The Economic Motivations for Using Project Finance. Harv. Bus. Sch., 28, 1-42, available online at https://www.researchgate.net/publication/228845708_The_Economic_Motivations_for using_Project_Finance

Engle, R. F., Giglio, S., Kelly, B., Lee, H. \& Stroebel, J. (2020), Hedging Climate Change News, Review of Financial Studies, 33(3): 1184-1216

Fama, E., French, K. (2020) Comparing Cross-Section and Time-Series Factor Models, Review of Financial Studies, 33(5): 1879-1890

Flammer, C. (2018), “Corporate Green Bonds," Available at SSRN :https://ssrn.com/abstract=3125518 or http://dx.doi.org/10.2139/ssrn.3125518

Floater, G, Dowling, D, Chan, D, Ulterino, M, Braunstein, J, McMinn, T and Ahmad, E. (2017a), Global Review of Finance for Sustainable Urban Infrastructure. Coalition for Urban Transitions, London and Washington DC. Available at: http://newclimateeconomy.report/workingpapers/workingpaper/global-review-of-finance for-sustainable-urban-infrastructure/

Floater, G., Dowling, D, Chan, D, Ulterino, M, Braunstein, J \& McMinn, T (2017b), Financing the Urban Transition: Policymakers' Summary. Coalition for Urban Transitions, London and Washington DC. Available at: http://newclimateeconomy.report/workingpapers/workingpaper/financing-the-urbantransition-policymakers-summary/

Giglio, S., Maggiori, M., Stroebel, J., \& Weber, A. (2015), Climate Change and Long-Run Discount Rates: Evidence from Real Estate, National Bureau of Economic Research, w21767,http://www.nber.org/papers/w21767

Giglio, S., Maggiori, M., Stroebel, J. \& Weber, A. (2019), Climate Change and Long-Run Discount Rates: Evidence from Real Estate, Working Paper.

Golosov, M., Hassler, J., Krusell, P., \& Tsyvinski, A. (2014), Optimal taxes on fossil fuel in general equilibrium, Econometrica, 82(1): 41-88

Green Bond Report (2019)

Heal, G., (2017), The Economics of the Climate, Journal of Economic Literature, 55: 1046-63.

Hong, H., Li, F. W., Xu, J. (2019), “Climate Risks and Market Efficiency,” Journal of Econometrics, 208 :265281.

Hong, H., Karolyi, G.A. \& Scheinkman, J. A. (2020), Climate Finance, Review of Financial Studies, 33(3): 10111023

Hughs, G., Chinowsky, P., \& Strzepek, K (2010), Development and climate change: The costs of adapting to climate change for infrastructure. Discussion Paper No. 2. The World Bank, Available at: http://siteresources.worldbank.org/EXTCC/Resources/4078631229101582229/DCCDP 2Infrastructure.pdf

IPCC (2018), "Global Warming of $1.5^{\circ} \mathrm{C}$. An IPCC Special Report on the Impacts of Global Warming of $1.5^{\circ} \mathrm{C}$ Above Pre-Industrial Levels and Related Global GHG Emission."

Jensen, M. C. (1986), Agency Costs Of Free Cash Flow, Corporate Finance and Takeovers, American Economic Review, 76(2): 323-329.

Jensen, M. C. \& Meckling, W. (1976), Theory of the Firm: Managerial Behavior, Agency Costs and Ownership structure, Journal of Financial Economics, 3: 305-360

Lustig, H., Roussanov, N., \& Verdelhan, A. (2011), Common Risk Factors in Currency Markets, Review of Financial Studies, 24 (11): 3731-3777

McKinsey (2016), Financing Change: How to Mobilize Private-Sector Financing for Sustainable Infrastructure. McKinsey Centre for Business and Environment (January 2016):1-68

Miller, M.H. (1977), Debt and Taxes, Journal of Finance, 32: 261-276.

Miller, M.H. (1988), The Modigliani-Miller Propositions After Thirty Years, Journal of Economic Perspectives, 2(4): 99-120.

Miller, M.H. (1998), The M\&M Propositions 40 years later, European Financial Management,4:113-120. 
Miller, M. H. (2000), The History Of Finance: an Eyewitness Account, Journal of Applied Corporate Finance, 13(2): 8-14. Miller, M.H. (2005), Leverage, Nobel Prize Lecture 1990 Reprint, Journal of Applied Corporate Finance, 17 (1): 106 - 111.

Miller, M. H., \& Modigliani, F. (1961), Dividend policy, Growth and the Valuation of Shares, Journal of Business, 34 (4): 411-433.

Modigliani, F. \& Miller, M. H. (1958), The Cost Of Capital, Corporation Finance and the Theory of Investment, American Economic Review, 48: 261-296

Modigliani, F. \& Miller, M. H. (1963), Corporate Income Taxes and the Cost of Capital: A correction, American Economic Review, 53: 433-443.

Murfin, J., Spiegel, M. (2020), Is The Risk of Sea-Level Rise Capitalized In Residential Real Estate? Review of Financial Studies, 33(3):1217-1255.

Myers, S.C.(1977),The Determinants of Corporate Borrowing, Journal of Financial Economics,5:147-175.

Myers, S.C. \& Majluf, N.S. (1984), Corporate Financing And Investment Decisions When Firms have Information the Investors do not Have, Journal of Financial Economics, 13:187-221.

Nordhaus, W. D. (1994), Managing the Global Commons: The Economics of Climate Change, MIT Press, Cambridge, Massachusetts.

Nordhaus, W.D., (2017a), Evolution of Assessments of the Economics of Global Warming: Changes in the DICE model, 1992 - 2017 (Working Paper No. 23319), National Bureau of Economic Research .https://doi.org/10.3386/w23319

Nordhaus, W.D., (2017b), Revisiting the Social Cost of Carbon. Proc. Natl. Acad. Sci.114:1518-1523. https://doi.org/10.1073/pnas.1609244114

Nordhaus, W.D., (2016), Projections and Uncertainties about Climate Change in an Era of Minimal Climate Policies (Working Paper No. 22933), National Bureau of Economic Research.

Nordhaus, W.D. (2015), A New Solution: The Climate Club. New York: Rev. Books.

Nordhaus, W. (2019), Climate change: The Ultimate Challenge for Economists, American Economic Review, 109: 1991-2014

Nordhaus, W.D., \& Sztorc, P., (2013), DICE 2013R: Introduction and User's Manual.

OECD (2016), Fragmentation in Clean Energy Investment and Financing In OECD Business and Finance Outlook 2016, OECD Publishing, Paris.

Painter, M. (2020), An Inconvenient Cost: The Effects Of Climate Change On Municipal Bonds, Journal of Financial Economics, 135(2): 468-482.

Pelling, M., Leck, H., Pasquini, L., Ajibade, I., Osuteye, E., Parnell, S., Lwasa, S., Johnson, C., Fraser, A., Barcena, A. \& Boubacar, S. (2018), Africa's Urban Adaptation Transition under a1.5 ${ }^{\circ}$ climate. Current Opinion in Environmental Sustainability, 31 10-15

Rogelj, J., den Elzen, M., Höhne, N., Fransen, T., Fekete, H., Winkler, H., Schaeffer, R., Sha, F., Riahi, F., \& Meinshausen, M (2016), Paris Agreement Climate Proposals Need A Boost To Keep Warming Well Below $2^{\circ} \mathrm{C}$. Nature. 534(7609):631-639

Roll, R. (1984), Orange juice and Weather, American Economic Review, 74(5): 861-880

Schlenker, W., \& Roberts, M. J., (2009), Nonlinear Temperature Effects Indicate Severe Damages to US Crop Yields Under Climate Change, Proc. National Academy of Sciences, 106(37):15594-15598

Schmidt, T.S. (2014), Low-Carbon Investment Risks and De-Risking, Nature Climate Change, 4:237-239.

Sharpe, W. F. (1964), Capital Asset Prices: A Theory of Market Equilibrium under Conditions of Risk, Journal of Finance, 19(3): 425-442

Shive, S. A., Foster, M. M. (2020), Corporate Governance and Pollution Externalities of Public and Private Firms, Review of Financial Studies, 33(3): 1296-1330

Steele, G. S. (2020), Confronting the 'Climate Lehman Moment': The case for Macro-Prudential Climate Regulation, Forthcoming Cornell Journal of Law and Public Policy.

Steffen, B. (2018), The importance of project finance for renewable energy projects, Energy Economics, 69:280294 https://doi.org/10.1016/j.eneco.2017.11.006

Stern, N., (2013), The Structure of Economic Modeling of the Potential Impacts of Climate Change: Grafting Gross Underestimation of Risk onto Already Narrow Science Models. Journal of Economic Literature 51: 838-859 https://doi.org/10.1257/jel.51.3.838

Stiglitz, J.E., Stern, N., Duan, M., Edenhofer, O., Giraud, G., Heal, G., Lèbre la Rovere, E.,Morris, A., Moyer, E., Pangestu, M., Shukla, P.R., Sokona, Y.S., \& Winkler, H. (2017), Report of the High-Level Commission on Carbon Prices, Carbon Pricing Leadership Coalition.

Stulz, R. M., (2005), The Limits of Financial Globalization, Journal of Finance, 60: 1595-1638

Summers, L., \& Zeckhauser, R., (2008), Policymaking for Posterity, Journal of Risk and Uncertainty, 37: 115140, https://doi.org/10.1007/s11166-008-9052-y

UNEP Centre/BNEF 2020.Global Trends in Renewable Energy Investment 2020, http://www.fs-unep-centre.org 
(Frankfurt am Main)

United Nations (2019a) World Population Prospects 2019, UN Department of Economic and Social Affairs

United Nations (2019b) World Urbanization Prospects 2018 Revision

Verdability

Sustainable

Energy

Infrastructure

Assets

https://www.verdability.com/insights/sustainable-energy-infrastructure-assets/ 